
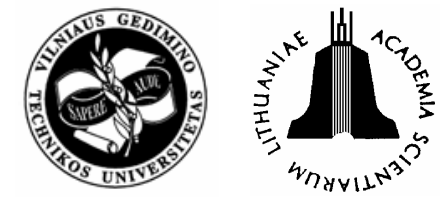

\title{
THE COMPRESSIVE STRENGTH PROPERTIES OF MINERAL WOOL SLABS: INFLUENCE OF STRUCTURE ANISOTROPY AND METHODICAL FACTORS
}

\author{
Andrius Buska ${ }^{1}$, Romualdas Mačiulaitis ${ }^{2}$ \\ Dept of Building Materials, Vilnius Gediminas Technical University, Saul tekio al. 11, LT-10223 Vilnius, \\ Lithuania.E-mail: ${ }^{2}$ andrius.buska@rockwool.lt; ${ }^{2}$ romualdas.maciulaitis@st.vtu.lt
}

Received 5 July 2006; accepted 7 Dec 2006

\begin{abstract}
This paper presents the research on the structure and compressive stress or compressive strength of mineral wool products. The products of chaotic, directional and combinative fibres structure have been studied visually and microscopically. During mechanical tests it was determined that compressive stress (compressive strength) of the stone wool products is dependent on the direction of the load working to the product major face, test specimen dimensions, force increasing rate, fibres distribution (orientation) and methodical peculiarities.
\end{abstract}

Keywords: mineral wool, stone wool, fibres, structure, compressive stress at $10 \%$ relative deformation, compressive strength, deformation.

\section{Introduction}

The thermal insulation products made of mineral wool depending on the orientation of fibres could be divided into the chaotic (the case when fibres are distributed randomly and in different directions irregularly) and the directional (the case when fibres are distributed in a certain order) $[1,2]$ in terms of the structure. The mineral wool products which have the directional fibres structure are called "lamella" [3]. Moreover, some products of the combinative fibres structure are used for certain constructions [4].

The dominating orientation of the fibres in the products of the directional structure is perpendicular to the surface of the insulated enclosure construction (wall, roof or floor base). The products of the directional fibres structure may be formed by packing, cubic and corrugating technology [4-6]. However, most often such products are produced by regulating the fibres direction on the belt conveyor or by forming mineral wool semiproduct layer of certain dimensions by a conveyor method. After the layer is cut in strips of the width equal to the original product thickness, and finally the strips are rotated at $90^{\circ}$ angle [7].

On the other hand, differences of the mechanical properties and deformation of the mineral wool products of the directional and random fibres structure appear to be not relevant. However, as construction practice shows, the contractors are often complaining about the irregular compressive stress (compressive strength) and deformation of slabs used for facade and roof thermal insulation. The assumption may be made that the compressive strength and other mechanical properties of mineral wool products depend on fibre distribution (orientation) in the product structure, the direction of the load working to the product major face etc [8-10].
The dependence of thermal and other particular properties of the mineral wool on fibre orientation, length and shape is very well-known and successfully used in production technologies of thermal insulation, structural, refractory and compositional materials [11-15]. A relatively large influence of the ambient temperature, test specimen strength and density, pressing of the measurement sensors to the test specimen on the coefficient of thermal conductivity of mineral wool products was determined during tests. Furthermore, according to the conversion formulas applied for this indicator, there are some application limits [16, 17]. However, there has been less research on influence of the same factors effecting the performance of thermal insulated materials (including stone wool), for instance, strength. In our opinion, this factor is insufficiently evaluated in the standards regulating the mechanical properties of mineral wool products and their measurement [18] because some methodical aspects of standards (force increasing rate, dimensions of the test specimens and their preparation before testing) are not strictly defined, especially in standards of different countries.

In order to determine the influence of fibre orientation in the product structure, the load direction in terms of the product in its intended use and some other methodical factors on the mechanical properties (compressive stress at $10 \%$ relative deformation $\left(\sigma_{10}\right)$ and compressive strength $\left(\sigma_{\mathrm{m}}\right)$ ) of the mineral wool slabs produced by belt conveyor technology, the following aspects have to be analysed:

- dependence of the product compressive stress on the test specimen dimensions and force increasing rate;

- dependence of the product compressive stress on the load direction;

- comparison of the product compressive stress with standards applicable in different countries. 


\section{Test specimens and methods}

\subsection{Description of test specimens and testing equipment}

Two types of the stone wool slabs produced by belt conveyor technology were used for testing:

1. $100-130 \mathrm{~kg} / \mathrm{m}^{3}$ density slabs with declared coefficient of thermal conductivity $\lambda_{\mathrm{D}} \leq 0,039 \mathrm{~W} /(\mathrm{m} \cdot \mathrm{K})$, whereas declared compressive stress at $10 \%$ relative deformation $\left(\sigma_{10}\right) \geq 30 \mathrm{kPa}$. The dimensions of the factory-made slabs were $1000 \times 600 \times 100 \mathrm{~mm}$. The amount of the organic content was determined by heating the slab fragments at $550{ }^{\circ} \mathrm{C}$ for two hours. The measured amount 3,7\% (by mass).

These test specimens were used by performing the research on the dependence of compressive stress and deformations of the mineral wool slabs according to the test specimen dimensions and force increasing rate (Chapter 3.3). The tests were performed by a universal electromechanic testing machine P-0,5 U4.2 (former USSR) and universal flexure/compression equipment ToniNorm ("Toni technik Gmbh", Germany) with integrated dataprocessing program “ToniTrol Expert” (Fig 1).

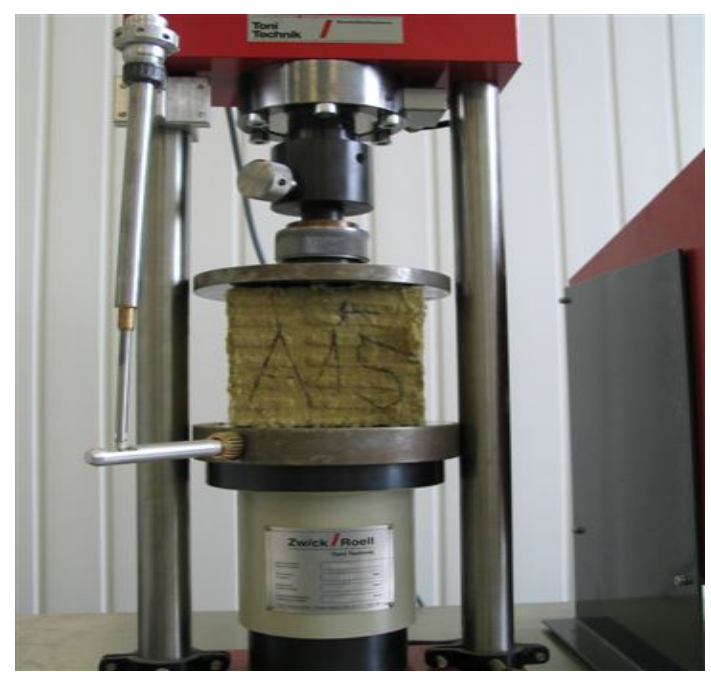

Fig 1. A specimen under load in the test machine "ToniNorm"

2. $100-150 \mathrm{~kg} / \mathrm{m}^{3}$ density slabs with declared coefficient of thermal conductivity $\lambda_{\mathrm{D}} \leq 0,039 \mathrm{~W} /(\mathrm{m} \cdot \mathrm{K})$, whereas declared compressive stress at $10 \%$ relative deformation $\left(\sigma_{10}\right) \geq 40 \mathrm{kPa}$. The dimensions of the factory-made slabs were $1000 \times 500 \times 100 \mathrm{~mm}$. The amount of the organic content was determined by heating the slab fragments at $550{ }^{\circ} \mathrm{C}$ for two hours. The measured amount was $4,5 \%$ (by mass).

These test specimens were used for the research on the dependence of compressive stress values in the direction of the load (Chapter 3.2) and comparable measurements of compressive stress by the standards of different countries (Chapter 3.4). Universal computer-integrated apparatus H $10 \mathrm{KS}$ (Housfield, England) determining strength of the thermal insulated products were used (Fig 2).

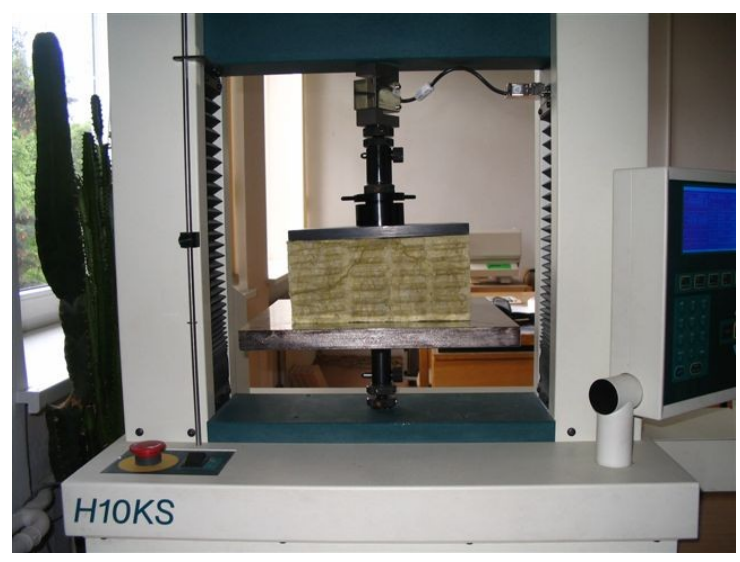

Fig 2. Compression testing machine H $10 \mathrm{KS}$

The mineral wool fibre structure during the research was studied visually and by optical and electronical microscopes:

- optical stereo binocular microscope "Steddy-T Bino 7300 " with photo appendage $(\times 2,5 \ldots \times 120)$;

- electronical microscope "JEOL JSM-5600" (maximum resolution $3,5 \mathrm{~nm}$, enlargement from $\times 18$ to $\times 300000$, tension increasing the electron flow $0,5-$ $30 \mathrm{kV})$.

Photos of the stone wool fibre and the product fragments made during the research are presented in this paper.

\subsection{Testing procedure}

LST EN 826. Compression behaviour (compressive stress and/or compressive strength) of the mineral wool products are determined in accordance with the requirements of the harmonised standards of the European Union and Lithuania LST EN 826 [19]. According to 6.1§ of this standard, the test specimens of various dimensions of the mineral wool products may be chosen. The test specimens shall be squarely cut, the dimensions of the sides have to be from $50 \mathrm{~mm} \times 50 \mathrm{~mm}$ to $300 \mathrm{~mm} \times$ $300 \mathrm{~mm}$. However, the test specimens' width shall not be less than their thickness. According to the standard, the test specimens' thickness must be the same as the original product thickness. Moreover, several test specimens shall not be put on each other in order not to modify the test specimen thickness [19].

Nevertheless, the standard for the factory made mineral wool products EN 13162 [18] indicates that the test specimens of the dimensions of only $200 \mathrm{~mm} \times 200 \mathrm{~mm}$ or $300 \mathrm{~mm} \times 300 \mathrm{~mm}$ may be chosen for testing. 5 measurements for one test result will be needed in the first case; whereas only 3 measurements in the second case. The surfaces of the specimens shall be prepared, ie surface grinded. The dimensions shall be determined with an accuracy of $0,5 \%$. The test shall be carried out at $(23 \pm 5){ }^{\circ} \mathrm{C}$. Special conditioning of the test specimens is not necessary (however, the test specimens shall be stored at $(23 \pm 5){ }^{\circ} \mathrm{C}$ and relative humidity at $(50 \pm 5) \%$ at least $6 \mathrm{~h}$ prior to testing, if necessary).

In order to ensure a close contact between the plates of the equipment and the test specimen surface, the test specimen is preloaded with a pressure of $(250 \pm 10) \mathrm{Pa}$. 
The test specimen compression period, ie force increasing rate, is dependent on the test specimen height, because it is compressed at a constant speed $0,1 \times d(d-$ the thickness of test specimen expressed in $\mathrm{mm}$ ) per min with a tolerance of $\pm 25 \%$.

The compression test is continued until the test specimen reaches the $10 \%$ relative deformation. Thus, compressive stress $\left(\sigma_{10}\right)$ is determined at $10 \%$ relative deformation. Compressive strength $\left(\sigma_{m}\right)$ is determined if the test specimen breaks up before reaching $10 \%$ relative deformation. It is necessary to define load-displacement curves during the research. The curve shows the dependence of the specimen deformation on load. Such curves provide additional information on the product behaviour.

$10 \%$ relative deformation of the test specimen is measured from "zero-deformation point" which is extended to zero force axis the steepest straight portion of load-displacement curve. Compressive stress $\left(\sigma_{10}\right)$ at $10 \%$ relative deformation is calculated after determining load at which the test specimen reaches the required deformation. If the test specimen yield or rupture before reaching $10 \%$ deformation, then the compressive strength $\left(\sigma_{m}\right)$ is determined under the maximum load value.

DIN 52272-1. Before the harmonised standard (EN 826) became effective, the determination of compression behaviour of the mineral fibrous insulating products in Germany was performed in accordance with the national standard DIN 52272-1 [20], effective since 1981. According to the requirements of this standard, the test specimens of the parallel faces in dimensions of only $200 \mathrm{~mm} \times 200 \mathrm{~mm}$ shall be used for testing. They shall be stored at least for two days before testing under normal conditions, ie at $(23 \pm 2){ }^{\circ} \mathrm{C}$ temperature and $(50 \pm 6) \%$ relative humidity. This standard did not define the precision and preparation of the test specimens. It only indicated that the test specimens were not usually processed. At least 5 test specimens shall be tested. According to the standard, the test specimen shall be preloaded with an initial pressure of $0,1 \mathrm{kN} / \mathrm{m}^{2}$ which has to be increased by a constant speed - $\max 20 \mathrm{~mm} / \mathrm{min}$ till $10 \%$ of relative deformation is reached or the test specimen yields.

The value of compressive stress at $10 \%$ relative deformation was determined according to load-displacement curve then the test specimen displaced the $10 \%$ relative deformation and subtracting initial compressive preload of $0,1 \mathrm{kN} / \mathrm{m}^{2}$.

GOST 17177-94. Inter-state standard of Commonwealth of Independent States, GOST 17177-94 [21], presents the measurement methods of the main performance of thermal insulation materials and products, including the methods for determining the compressive stress at $10 \%$ of the mineral wool products deformation. The standard indicates that square test specimens in length and width of $(100 \pm 1) \mathrm{mm}$ shall be used for testing. Their thickness shall be equal to the original product thickness. If the test specimen dimensions are measured by a rule tape, the acceptable measurement tolerance shall be $\pm 0,5 \mathrm{~mm}$. If they are measured by sliding callipers, the precision shall be $\pm 0,1 \mathrm{~mm}$. The tests shall be carried out at $(22 \pm 5){ }^{\circ} \mathrm{C}$. Minimum number of the test specimens is indicated in the relevant product standard. In this case, 2 test specimens out of 3 slabs were cut. 6 measurements were in total. Any preload is not indicated in the standard; however, $10 \%$ linear deformation of the test specimen is measured only after loading the test specimen at $(2000 \pm 100) \mathrm{Pa}$. The test specimen is affected by load by increasing it from 5 to $10 \mathrm{~mm} / \mathrm{min}$. The value of compressive stress $\left(\sigma_{10}\right)$ is determined when the test specimen reached $10 \%$ of relative deformation.

\section{Results of experimental research and discussion}

\subsection{Evaluation of the fibre structure in the stone wool slabs}

The stone wool products of the chaotic and directional fibres structure were analysed and evaluated during this research. These products are used as the thermal insulation layer in external plastered thermal insulation composite systems (ETICS) [22] as base for the decorative plaster layer of a different variety.

The stone wool products with the orientated fibres structure (lamellas) are produced by different manufacturers and seemed to be similar after their examination; however, they differed visually in a bigger or smaller expression of the fibres orientation. Discernible singleness of the fibres orientation remains the same in crosssections of the test specimens prepared for a compression test.

After examining the fragments of the stone wool products of the chaotic orientation fibres structure which are prepared for compression tests, it is obvious that their structure is not homogeneous mainly because of an unevenly distributed binder. Light-coloured areas, though orientated in the same direction just like the fibres in the product structure, are more elongated or flattened without the binder in each cross-section (Fig 3). This shows that the spatial fibres structure of the product is formed during the product formation process. Such structure is formed by collecting and after towards compressing the thermally uncured (before the binder has been cured) wool layer by the movable belt conveyor network.

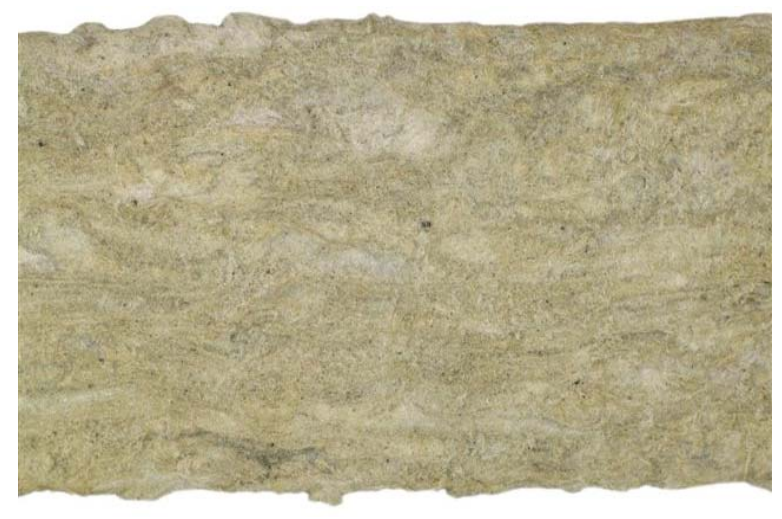

Fig 3. Distribution of fibres in the chaotic orientation of the stone wool slab structure (per product thickness) 
In the issue, it would be difficult to state that such products might be attributed to the products of the chaotic structure. They seemingly are of the mixed structure.

Such attitude is based on the other fact that the fibres strands and single fibres compressed during the formation are set to each other in one direction but they engage with each other by intertwining regarding frictional force and the formation conditions. Therefore they retain the required structure even in the case the binder heated. It is stated that the fibres quantity of up to 60-85\% distributes in horizontal plane (in the same direction as moves belt conveyor line) during the formation process [23]. Unfortunately, the difficulties concerning the problem of the allegedly directional structure formation are also met in other manufacture processes of building materials and products which include extrusive [24], fibres pulp processing [25] etc.

According to the authors [25], the analysis of fibres by a microscope enables to display not only the fibres, but also non-fibrous melt inserts ("little pearls") and their the form, diameter, contact peculiarities, flaxes and dusts of inserts, hollows and groups of thickened fibres in the stone wool products of a different variety. The single fibres, their contact zones (Fig 4) and various defects such as the binder drops and pieces of non-fibrous melt inserts ("little pearls") (Fig 5) were examined by using the electronic scanning microscope.

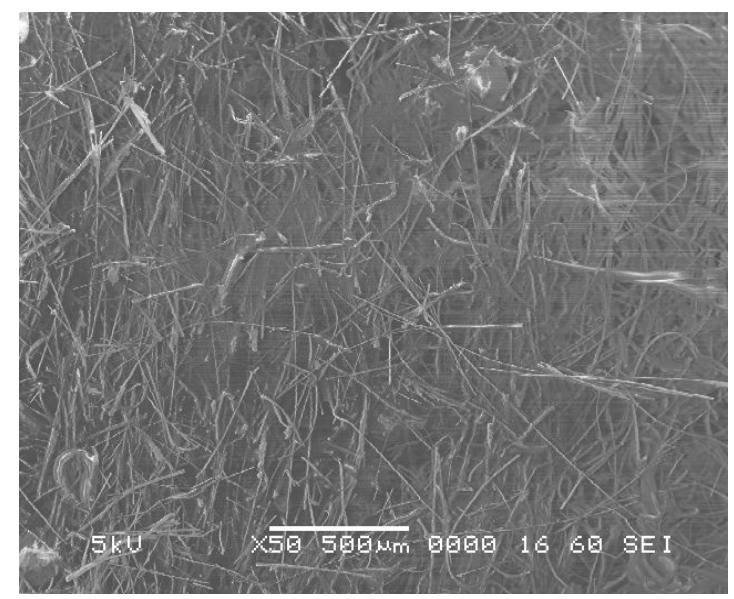

Fig 4. Photo of the fibres in the orientated fibres structure of stone wool product (lamella) (enlarged $\times 50$ times)

One may state that the form and diameter of the fibres of the products manufactured by the same technological production line and the form of the non-fibrous melt inserts ("little pearls") are almost identical.

Moreover, this condition does not depend on the fibres orientation in the product structure. But it is likely that such condition is influenced by identical raw materials and the same equipment used for spinning (fibres production) from the melt.

Nevertheless, the structure of the stone wool products may be very chaotic and the binder added during the production process may be distributed relatively unevenly in the product volume. The chaotic condition of its structure is related to the micro-structural level of the stone wool slab. For instance, the wad of the fibres randomly formed during the product formation process. However, it is not related to the dominating fibres orientation in the product structure which is typical of both, the lamellas and the stone wool products of the random fibres orientation that have no clearly expressed fibres orientation.

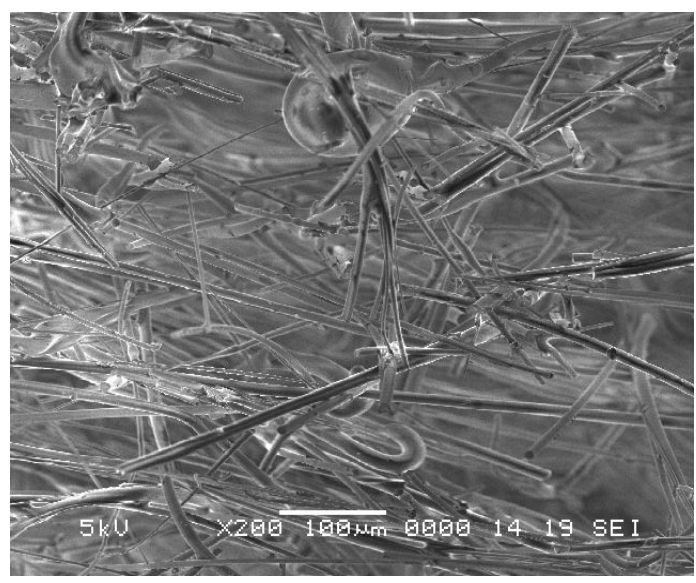

Fig 5. Fibres and pieces of the non-fibrous melt inserts ("little pearls") (enlarged $\times 200$ times)

The research performed enables to identify and describe only the smallest peculiarities of the fibrous product structure which contains dozen of the fibres or the area of $3-5 \mathrm{~mm}^{2}$ at best. Therefore, it is almost impossible to see clearly directional stone wool fibres structure (Fig 6).

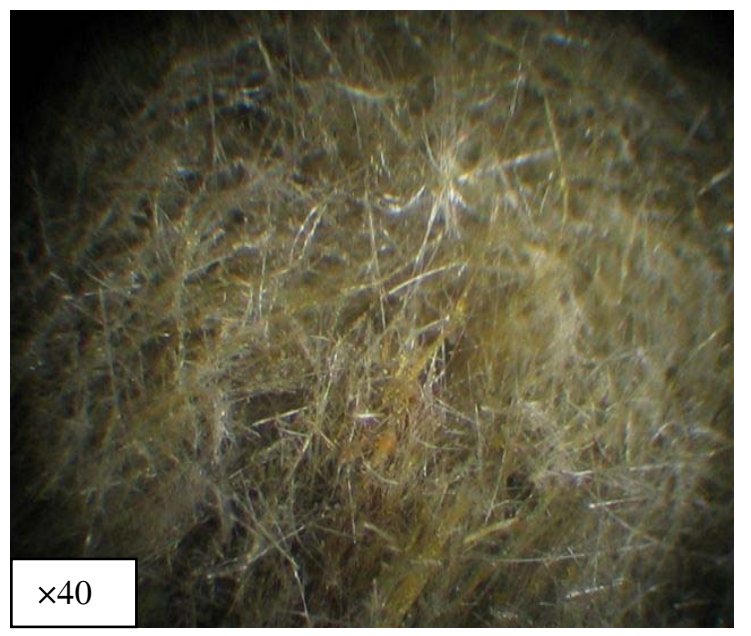

Fig 6. Picture of the stone wool slab fragment of the allegedly random fibres structure through eyepiece of optical microscope (enlarged $\times 40$ times)

Thus we may state that the well-known and generally received structure classification into groups has essential weaknesses since, most probably, there are no ideally made products of one or another structure.

Realistic assumption would be that compressive stress (compressive strength) and deformation of the stone wool products and other mechanical properties are dependent on both, the fibres orientation in the product structure and the direction of the mechanical action (the load working) which dominates with regard to the major face of the fibres orientation product. 


\subsection{Dependence of compressive stress (compressive strength) on the load working direction}

Materials of the spatial fibrous structure usually are anisotropic since their properties are uneven in various directions. The distribution of the fibres in terms of one certain direction changes the values of the different material characteristics. Compressive and tensile strength, thermal conductivity mostly depend on the fibres orientation [26].

It is known that the majority of the fibres are orientated in horizontal direction in the mineral wool products produced by the conveyor technology [5]. Therefore the compressive stress $\left(\sigma_{10}\right)$ at $10 \%$ of relative deformation or compressive strength $\left(\sigma_{\mathrm{m}}\right)$ of the test specimens depends on the load working direction.

The test specimens of $100 \mathrm{~mm} \times 100 \mathrm{~mm}$ and in height of $100 \mathrm{~mm}$ cut from the same stone wool slab were tested by compressive load functioning in various directions. The direction of the compressive load working with regard to the fibres orientation in the product structure is shown in Fig 7.

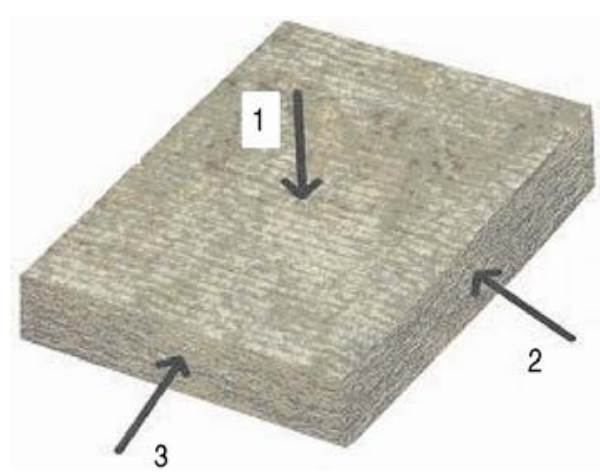

Fig 7. Directions of possible compressive load working: allegedly perpendicular (1); allegedly parallel (2); allegedly tangential (3)

Marking of the load working direction was chosen according to the wool layer movement on the conveyor (by production line direction) and visible conveyor belt pattern on the product surface.

The average of the 5 results obtained during the research is illustrated in Fig 8.

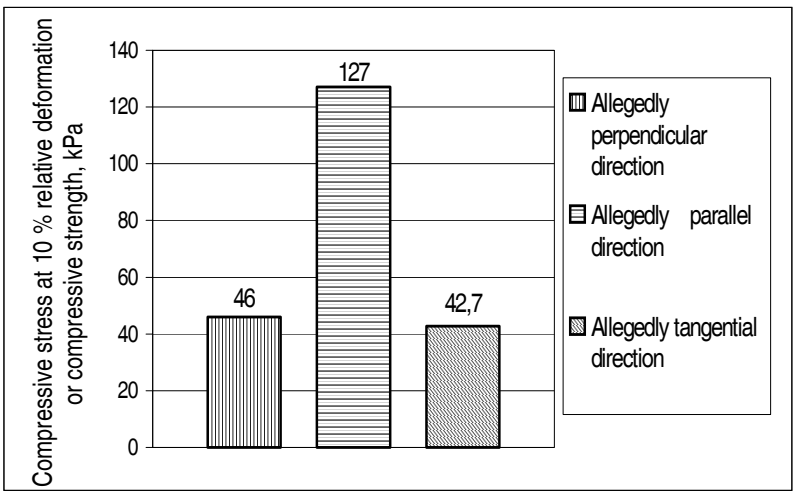

Fig 8. Measured values of compressive stress at $10 \%$ of relative deformation and compressive strength depending on the load working direction
The test specimens compressed in the dominating direction of the fibres ( $2^{\text {nd }}$ direction) initially deformed more slowly and their deformation curve at the initial compression stage was more upright. However, the test specimens ruptured suddenly when $5-6 \%$ of deformations were reached.

Accordingly, the test specimens compressed in the $1^{\text {st }}$ and $3^{\text {rd }}$ directions deformed gradually and strength increased more slowly at the beginning of load. When the test specimen reached approx $4 \%$ of deformation, the increase of strength lowered in comparison to deformation. A more significant flexure of the curves was recorded when the test specimens reached 6-7\% of deformation. All the kinetic deformation curves of the test specimens are in Fig 9.

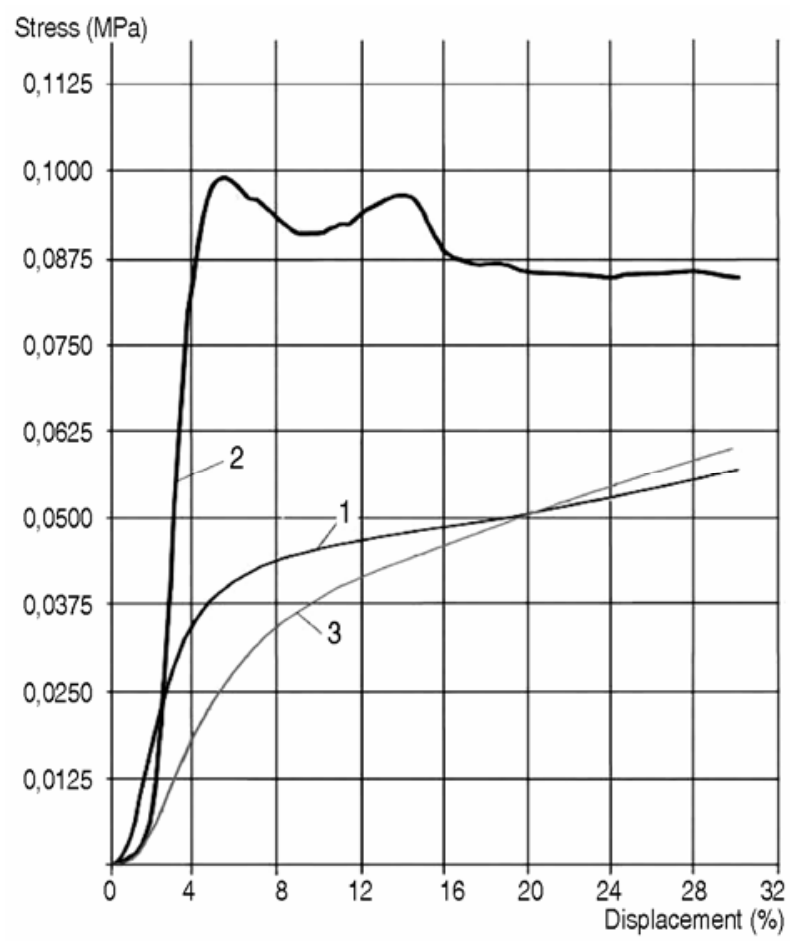

Fig 9. Deformation curves depending on the direction of the compressive load working (according to Fig 7): allegedly perpendicular (1); allegedly parallel (2); allegedly tangential (3)

In accordance with the chaotic (allegedly random) fibres orientation in the product and the test specimens cut from the slabs, including the singleness of the fibres and its defective areas influenced by production technology, it is possible to classify three possible directions of the compressive load action in terms of the different compression results obtained.

These directions are as follows: allegedly perpendicular, because it is perpendicular to the product surface and the conveyor surface of the production line (curve 1 according to Fig 7), allegedly parallel, because it is parallel to the product surface and the conveyor axis of the production line (curve 2 according to Fig 7), allegedly tangential, because it is parallel to the product surface and perpendicular to the conveyor axis of the production line (curve 3 according to Fig 7). 
Table 1. Compressive stress at $10 \%$ of relative deformation $\left(\sigma_{10}\right)$ and compressive strength $\left(\sigma_{\mathrm{m}}\right)$ of the test specimens of the allegedly random fibres structure

\begin{tabular}{l|c|c|c|c}
\hline $\begin{array}{c}\text { Directions of the fibres } \\
\text { orientation in the product } \\
\text { structure }\end{array}$ & $\begin{array}{c}\text { Direction of load } \\
\text { working (according } \\
\text { to Fig 7) }\end{array}$ & $\begin{array}{c}\text { Average values of compressive stress } \\
\text { at 10\% of relative deformation }\left(\sigma_{10}\right) \\
\text { and compressive strength }\left(\sigma_{\mathrm{m}}\right), \mathrm{kPa}\end{array}$ & $\begin{array}{c}\text { Average } \\
\text { density, } \\
\mathrm{kg} / \mathrm{m}^{3}\end{array}$ & $\begin{array}{c}\text { Average amount } \\
\text { of binder, } \\
\%\end{array}$ \\
\hline Allegedly perpendicular & 1 & $56,2^{*}$ & 145,4 & 3,25 \\
\hline Allegedly parallel & 2 & $142,4 * *$ & 152,7 & 3,11 \\
\hline Allegedly tangential & 3 & $50,9^{*}$ & 154,0 & 3,14 \\
\hline
\end{tabular}

Note: $*$ - compressive stress at $10 \%$ of relative deformation $\left(\sigma_{10}\right) ; * *$ - compressive strength $\left(\sigma_{\mathrm{m}}\right)$.

Furthermore, similar results were obtained by testing the test specimens of a different (higher) density which were cut from the stone wool slabs of the fibres structure of the allegedly random orientation. For instance, the average compression values of the stone wool test specimens in nominal density of $150 \mathrm{~kg} / \mathrm{m}^{3}$ are presented in Table 1.

According to the dates presented in Table 1, ie the different values of compressive stress at $10 \%$ of relative deformation (compressive strength), the results could have not been influenced by the deviations of density of the stone wool and of small amounts of the binder.

Nevertheless, primary results would prove that in case when the density of mineral wool increases, the difference between compressive stress (compressive strength) and other indicators depending on the direction of compressive load working has a tendency to decrease. However, this statement requires to be proven.

The research confirmed a crucial influence on the orientation of fibres in randomly or directionally formed product structure on the mechanical properties of the compressed stone wool products. The allegedly directional fibres orientation is very relevant to the mechanical properties of a product because "the influence of compressive load is absorbed mostly by the fibres which are characteristic of larger rigidity unlike the synthetic binder" [27].

The obtained results enable to specify the approach by other authors who claim that compressive stress of the mineral wool test specimens compressed in different directions at $10 \%$ of relative deformation may differ by 4-6 times [4]. These numbers are rather too heighted since our research showed that the difference for the stone wool of the studied density was only 2,5-3 times. It should be noticed that modern production technology of the mineral wool improved; thus anisotropy of the fibres structure decreased as well. In other words, possibilities to regulate and control micro- and macro-structure more accurately are enhanced.

\subsection{Dependence of compressive stress of the product on the test specimen dimensions and force increasing rate}

It is known that indefiniteness of the test methodology of standardised building materials influences the test results [28, 29]. Therefore after determining the dependencies of the mechanical-deformative properties of the mineral wool products on various methodical factors it is possible to adequately evaluate the results which are obtained during the standardised tests and the values which are presented in technical descriptions in order to relate them to the actual performance of the mineral wool products.

As discussed in Chapter 2.2, force increasing rate of the test specimens used during the research (ie compression period as well) is chosen in accordance with $7.2 \S$ of the standard LST EN 826 [19]. This speed depends on the test specimens' height (thickness) as well because it is required to compress the test specimen till $10 \%$ of relative deformation in a certain time period (the higher the test specimen, the greater force increasing rate). The test specimens of two different dimensions $(100 \mathrm{~mm} \times$ $100 \mathrm{~mm} \times 100 \mathrm{~mm}$ and $200 \mathrm{~mm} \times 200 \mathrm{~mm} \times 100 \mathrm{~mm}$ ) were used for the research. Their force increasing rates were different. Thus the compression period for the test specimens of $100 \mathrm{~mm}$ height was $60 \mathrm{sec}$, whereas it shall be from 45 to $75 \mathrm{sec}$ in accordance with tolerance of $\pm 25 \%$ of those indicated in the standard.

In our opinion, this compressed time interval of the test specimens $(45-75 \mathrm{sec})$ is sufficient to obtain the very different values of compressive stress.

The value of compressive stress of the tested stone wool test specimens depends on dimensions and force increasing rate of the test specimens (Fig 10). Compressive stress of the test specimens of the larger dimensions $(200 \mathrm{~mm} \times 200 \mathrm{~mm})$ was greater by $9-11 \%$ than the test specimens of $100 \mathrm{~mm} \times 100 \mathrm{~mm}$ dimensions. If we evaluate only the test results which were obtained by compressing the test specimens at a speed specified in the standard, then the numeric values range from $36,6 \mathrm{kPa}$ to $32,7 \mathrm{kPa}$ respectively. Moreover, the scatter of the values of compressive stress of the test specimens with different dimensions also differs. According to the test results, scatter of compressive stress values was greater than the test specimens of smaller dimensions.

The choice of force increasing rate has influenced the value of compressive stress, ie the greater the force increasing rate, the higher values of a compressive stress. The values of compressive stress of $200 \mathrm{~mm} \times 200 \mathrm{~mm}$ test specimens at a certain force increasing rate are as follows: $43 s=37,5 \mathrm{kPa}$ and $75 s=34,9 \mathrm{kPa}$. Accordingly, the values of compressive stress of $100 \mathrm{~mm} \times$ $100 \mathrm{~mm}$ test specimens are: $45 \mathrm{~s}=41,5 \mathrm{kPa}$ and $95 \mathrm{~s}=$ $25 \mathrm{kPa}$. The difference may reach 1,5 time when comparing the lowest and the greatest values achieved during the tests.

One should notice that the uneven less of the stone wool fibres structure, the amount of non-fibrous inserts and other defects in product structure have an influence 


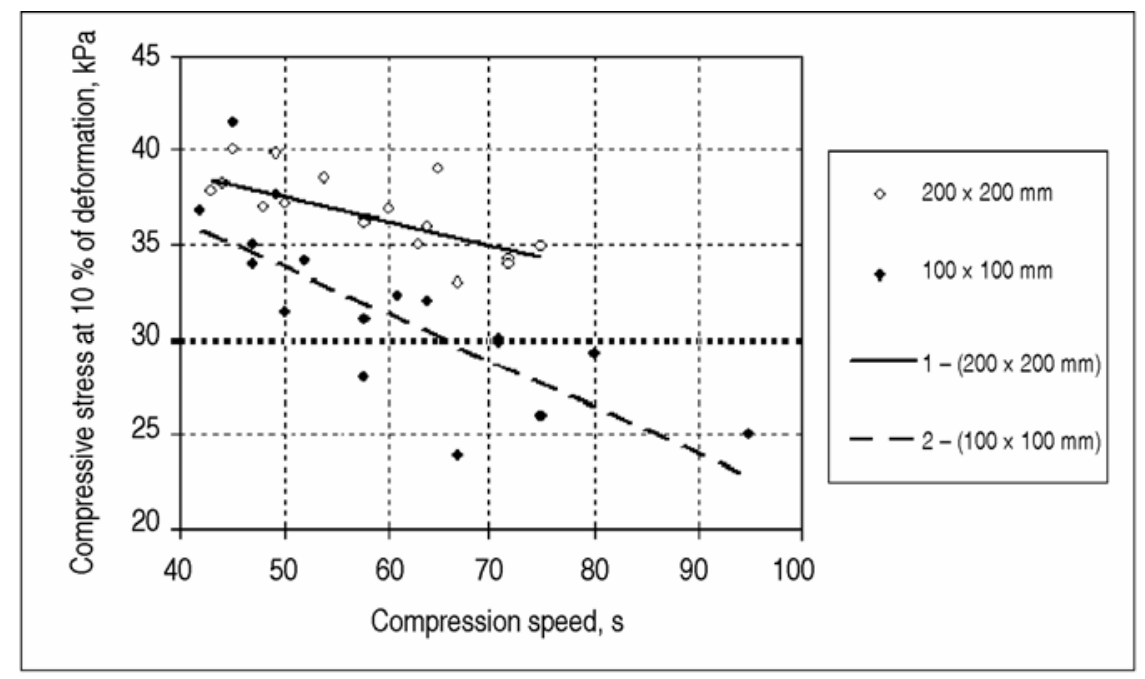

Fig 10. The values of compressive stress of the stone wool test specimens of different dimensions $(100 \mathrm{~mm} \times 100 \mathrm{~mm}$ and $200 \mathrm{~mm} \times 200 \mathrm{~mm}$ ) determined during research and their dependence on the compression time

on the measured lower values of compressive stress of the test specimens with $100 \mathrm{~mm} \times 100 \mathrm{~mm}$ dimensions and their distribution compare with the test specimens of $200 \mathrm{~mm} \times 200 \mathrm{~mm}$ dimensions.

Regression equations, determination $\left(R^{2}\right)$, correlation coefficients $(R)$ and average standard deviations $(s)$ were estimated in order to evaluate the functional dependence between compressive stress of the test specimens and their force increasing rate. These indicators describe the rectilinear degree of the measured values and the strength of a relationship. Regression equation of the dependence of compressive stress $\left(\sigma_{10}\right)$ of $200 \mathrm{~mm} \times$ $200 \mathrm{~mm}$ test specimens on the period of compressive time is as follows:

$$
\sigma_{10}=43,85-0,1257 \cdot x \text {, }
$$

where $x$-period of compress time, $\mathrm{s}$.

Determination coefficient of $200 \mathrm{~mm} \times 200 \mathrm{~mm}$ test specimens $R^{2}=0,888$, correlation coefficient $R=0,942$, average standard deviation $s= \pm 0,495 \mathrm{kPa}$.

Regression equation of $100 \mathrm{~mm} \times 100 \mathrm{~mm}$ test specimens:

$$
\sigma_{10}=46,21-0,2472 \cdot \mathrm{x},
$$

where $x$-period of compressive time, $\mathrm{s}$.

Determination coefficient $R^{2}=0,554$, correlation coefficient $R=0,744$, average standard deviation $s= \pm 3,36 \mathrm{kPa}$. Preliminarily, it could be stated that the algorithm of the equation (2) is insufficiently reasoned in terms of a mathematical aspect.

The correlation coefficients calculated show that the linear regression dependence exists between the compressive stress of the test specimens and their force increasing rate because the points are placed around the line, whereas correlation coefficient approaches Fig 1. Thus it is possible to obtain different results of compressive stress $\left(\sigma_{10}\right)$ of the stone wool slabs during the research by having the test specimens of different dimensions cut from the same slab. It is natural that the values of determination and correlation coefficients are lower for the test specimens with smaller dimensions. This is logical in terms of the plane of the structure and uneveness.

\subsection{Comparison of the values of the product compressive stress in accordance with different standards}

The influence of the methodical factors determining the compression behaviour of the mineral wool products on the declared values was evaluated by comparing the results obtained in accordance with different methodical standards. Compressive stress of the identical mineral wool products at $10 \%$ of relative deformation was determined according to the methods indicated in the following standards:

1) The harmonised standard of the European Union and Lithuania LST EN 826:1998 [19];

2) The German standard DIN 52272-1 [20];

3) The Inter-state standard of Commonwealth of Independent States GOST 17177-94 [21].

The results obtained during the tests are presented in Table 2.

As these results show, the greatest value of compressive stress at $10 \%$ of relative deformation $(57,4 \mathrm{kPa})$ was measured by the standard LST EN 826. This value is higher by $3,8 \%$ than the value measured by DIN 52272-1 $(55,4 \mathrm{kPa})$ and higher even by $21 \%$ than the value measured by GOST $17177-94(47,5 \mathrm{kPa})$. Accordingly, the aforementioned value is higher by $16,6 \%$ by the standard DIN 52272-1, when comparing to GOST 17177-94 methods.

The assumption may be made that the smaller dimensions of the test specimens $(100 \mathrm{~mm} \times 100 \mathrm{~mm})$ and force increasing rate $(5 \mathrm{~mm} / \mathrm{min})$ had the largest influence on the results obtained by GOST 17177-94 methods. According to the requirements of the standards LST EN 826 and DIN 52272-1, the test specimens of the larger dimensions (ie $200 \mathrm{~mm} \times 200 \mathrm{~mm}$ ) were used for testing. Moreover, force increasing rate and the position of the "zerodeformation point" of the test specimens differed (as 
Table 2. The values of compressive stress and density of the stone wool test specimens determined during the comparative tests

\begin{tabular}{|c|c|c|c|c|c|c|}
\hline \multirow[t]{2}{*}{ Number of test specimen } & \multicolumn{3}{|c|}{ Density, $\mathrm{kg} / \mathrm{m}^{3}$} & \multicolumn{3}{|c|}{$\begin{array}{l}\text { Compressive stress of } 10 \% \text { of relative deformation, } \\
\qquad \mathrm{kPa}\end{array}$} \\
\hline & EN & DIN & GOST & EN & DIN & GOST \\
\hline 1 & 127,5 & 119,4 & 118,7 & 58,5 & 53,0 & 42,6 \\
\hline 2 & 135,3 & 126,0 & 129,5 & 63,9 & 55,7 & 52,7 \\
\hline 3 & 120,7 & 125,7 & 132,4 & 52,2 & 55,8 & 49,2 \\
\hline 4 & 127,4 & 134,9 & 118,0 & 58,9 & 58,0 & 45,0 \\
\hline 5 & 125,2 & 124,0 & 125,8 & 54,2 & 54,6 & 44,5 \\
\hline 6 & - & - & 129,5 & - & - & 50,9 \\
\hline Average value & 127,2 & 126,0 & 125,7 & 57,4 & 55,4 & 47,5 \\
\hline Standard deviation & 5,3 & 5,6 & 6,0 & 4,6 & 1,8 & 4,0 \\
\hline
\end{tabular}

required in an appropriate standard). By comparing the results obtained by DIN 52272-1 and LST EN 826, when the test specimens of the same dimensions were compressed at a different speed (20 and $10 \mathrm{~mm} / \mathrm{min}$ ), it may be stated that the force increasing rate had no large effects on the results.

The value of compressive stress of the stone wool test specimens measured by different methods was similar, although the compress speed was doubly different. Most probably, the difference of the values of compressive stress decreased regarding the position of the "zerodeformation point" of the different results (loaddisplacement curve) by measuring $10 \%$ of the test specimens deformations.

The density of the specimens tested under different methods slightly differed (deviation $5,3-6,0 \mathrm{~kg} / \mathrm{m}^{3}$ ). Therefore it is considered to be a random and very small. Consequently, it had no large influence on the obtained results. However, the reduction of compressive stress of the test specimens of a smaller size when comparing to a random difference of their density is disproportionately large. This could not be explained by a lower density of the tested specimens. It is obvious that the smaller dimensions of these specimens strongly influenced the results. It is possible to say that stress relaxation is slower in the smaller dimensions of test specimens. It is the unevenness of the stone wool fibres structure and the defects (areas with the decreased or increased amount of the binder, inserts of the non-fibrous melt etc) that have a greater effect (more than by four times in the test specimens of a larger compressive area). A more extensive and intense structural research on the mineral wool is needed in order to explore this issue.

\section{Conclusions}

1. The model of "the structure of mass of fine intertwined fibres" consisting of flexible vitreous mineral fibres, non-fibrous melt inserts ("little pearls") and the resin binder, which connects them by a contact method, is applied for describing the man-made mineral wool. As the microscopic research showed, such model of the stone wool structure is practical only in terms of the microstructure. However, larger derivatives of its structure such as singleness of the fibres and areas with a smaller amount of the binder etc should be considered on the real macro-structural level.
2. The direction of the load working with regard to the major product face and the orientation of the fibres in the product structure considerably change the values of compressive stress at $10 \%$ of relative deformation and/or compressive strength of the stone wool slabs. The greatest value of compressive strength obtained when testing the test specimens, the fibre orientation of which in the product structure was parallel to the major product face and was coincident with the direction of the load working. The density deviations $\left(5,3-6,0 \mathrm{~kg} / \mathrm{m}^{3}\right)$ of the stone wool test specimens which were cut from the same slab but from different places are relatively small and have no crucial effect on the compressive stress value.

3 . The value of compressive stress at $10 \%$ of relative deformation of the stone wool products depends: firstly, on the methodology (the test specimens' dimensions, force increasing rate and other factors) used in the research (testing); secondly, on the peculiarities of results' evaluation procedure (on the estimation of the position of the "zero-deformation point" in load-displacement curves). The obtained results enable to confirm that the compressive stress of the stone wool test specimens depends to a larger extent on the test specimens' dimensions and to a lesser extent - on the speed of compression (force increasing rate). The average compressive stress (compressive strength) of the test specimens with smaller dimensions is apparently lower than compressive stress (strength) of the test specimens with larger dimensions. In the first instance, this reduction of compressive stress is related to the factor of a scale, ie the influence of the defects in the internal structure increases in the test specimens with small dimensions.

4. The differences of the tests methodology in terms of their probable influence on the results (values) of the declared values (properties) should be considered when are compared and evaluated with mechanical behaviour of the mineral wool products produced in the countries with different standard systems. Such methodological aspects like dimensions of the tested specimens, force increasing rate should be indicated in test reports.

\section{References}

1. MARČIUKAITIS, G. Principles of creation and properties prognostication of building composites. Vilnius: Technika, 1998. 134 p. (in Lithuanian). 
2. Structure of materials (anisotropy and isotropy). From: NTD Resource centre. Located at: http://www.ndted.org/ EducationResources/CommunityCollege/Materials/ Structure/anisotropy.htm (View 2006-01-27).

3. BS 3533:1981. Glossary of thermal insulation terms. British Standards Institution, London, 1981. $16 \mathrm{p}$.

4. BOBROV, J. L. Durability of the mineral wool materials (Долговечность теплоизоляционных минераловатных материалов). Moscow: Stroyizdat, 1987. 168 p. (in Russian).

5. STRAZDAS, K. and EIDUKEVIČIUS, J. Mineral and glass fibres. Vilnius: Mokslas, 1985. 224 p. (in Lithuanian).

6. KUDZIAVIČIUS, G. and GVAZDAUSKAS, P. Technology of production of mineral wool panels with vertical orientated fibres. In Transactions on Thermal Insulation: Technology of Thermal Insulation and Aacoustical Materials Made from Mineral Wool (Сб. научн. тр. «Технология теплоизоляционных и акустических материалов на основе минеральной ваты»). Vilnius, 1987. 124 p. (in Russian).

7. ZAROVNIATNYCH, V. A.; PONOMAREV, V. A.; BIRIUCEV, V. I. and DEMENEV, N. V. The experience of production of stitched mineral wool mats with vertical orientated fibres. Building Materials (Строительные материалы), 2002, 11, p. 17-19 (in Russian).

8. BUSKA, A. and KERBELIS, R. Influence of some factors upon mechanical and deformation characteristics of mineral wool slabs. In Proc of 7th National Conference of Junior Researchers "Lithuania without science - Lithuania without future”, Vilnius, 25-26 March 2004. Vilnius: Technika, 2004, p. 169-177 (in Lithuanian).

9. BUSKA, A. The dependence of the methodical factors on the compressive strength of mineral wool. In Proc of $\mathrm{Na}$ tional Conference of Science and Industry in Lithuania "Progressive Construction", Kaunas, 28-29 April 2005. Kaunas: Technologija, 2005, p. 84-93 (in Lithuanian).

10. BUSKA, A. and GAILIUS, A. Determination of compression behaviour of mineral wool slabs according to the different standards. In Proc of 8th National Conference of Junior Researchers "Lithuania without science - Lithuania without future”, Vilnius, 24-25 March 2005. Vilnius: Technika, 2005, p. 3-11 (in Lithuanian).

11. KRIVELIS, T. and KAMINSKAS, A. Spray-applied thermal insulation material of loose mineral wool. Materials Science (Medžiagotyra), 2000, 6(3), p. 204-208 (in Lithuanian).

12. JOHN, V. B. Introduction to engineering materials. New York: Macmillan Publishing Company, 2003. 376 p.

13. ENDRIUKAITYT , A.; PARASONIS, J.; SAMAJAUSKAS, R. and BLIŪDŽIUS, R. Estimation of effect of thermal convection on heat transfer through the building. Journal of Civil Engineering and Management, 2003, 9, Suppl 1, p. 66-76.

14. GNIP, I. and KERŠULIS, V. Thermal technical properties of eco-cotton. Statyba (Civil Engineering), 1998, 4(1), p. 43-48 (in Lithuanian).

15. BRATUCHIN, A. G.; SIROTKIN, P. F.; SABODASH, P. F. and JEGOROV, V. N. Materials of the future and their incredible properties (Материалы будущего и их удивительные свойства). Moscow: Mashinostrojenie, 1995. 126 p. (in Russian).

16. ZABOTKA, A.; BOLŠAITIS, R. and MATULIONIEN , V. The investigation of fibrous insulating materials heat con- ductivity at temperature range $-5 \div 25^{\circ} \mathrm{C}$. In Proc of $\mathrm{Na}$ tional Conference Construction and Architecture, Kaunas, 8-10 April 1998. Kaunas: Technologija, 1998, p. 325-328 (in Lithuanian).

17. ZABOTKA, A.; BOLŠAITIS, R. and MATULIONIEN , $\mathrm{V}$. The measurement of the fibrous materials thermal conductivity using hot-wire method. In Proc of National Conference Construction and Architecture, Kaunas, 9-11 April 1997. Kaunas: Technologija, 1997, p. 67-71 (in Lithuanian).

18. EN 13162:2001. Thermal insulation products for buildings - factory-made mineral wool (MW) products Specification. European Committee for Standardization, Brussels, 2001. 31 p.

19. LST EN 826:1998. Thermal insulation products for building applications. Determination of compression behaviour (Statybin s termoizoliacin s medžiagos. Stiprio gniuždant nustatymas). Lithuanian Standards Board, Vilnius, 1998. 12 p. (in Lithuanian).

20. DIN 52272-1. Testing of mineral fibrous insulating materials; pressure test; evaluation of compressive stress and resistance to compression (Prüfung von mineralfaserdämmstoffen Druckversuch Ermittlung der Druckspannung und Druckfestigkeit). German Institute for Standardization, Berlin, 1982. 4 p. (in German).

21. GOST 17177-94. Thermal insulating materials and products for building application. Test methods (Материалы и изделия строительные теплоизоляционные. Методы испытаний). State Committee for Standardization and Metrology, Moscow, 1994. 60 p. (in Russian).

22. ETAG 004:2000. Guideline for European technical approval of external thermal insulation composite systems with rendering. The European Organisation for Technical Approvals, Brussels, 2000. 87 p.

23. EIDUKEVIČIUS, K. K. Strengthening of mineral wool articles by means of the orientated fibre structure formation. Building Materials (Строительные материалы), 1984, 6, p. 6-8 (in Russian).

24. SOROUSHIAN, P.; ELZAFRANEY, M.; NOSSONI, A. and CHOWDHURY, H. Evaluation of normal-weight and light-weight fillers in extruded cellulose fibres cement products. Cement and Concrete Composites, 2006, 28(1), p. 69-76.

25. MOHR, B. J.; NANKO H. and KURTIS, K. E. Aligned kraft pulp fibre sheets for reinforcing mortar. Cement and Concrete Composites, 2006, 28(2), p. 161-172.

26. STRAZDAS, K. Chemical technology of glass and glass products. Kaunas: Technologija, 1998. 503 p. (in Lithuanian).

27. GNIP, I. J. Long-term strength of the rigid mineral wool plates. In Transactions on Thermal Insulation: Technology of Thermal Insulation and Acoustical Materials Made from Mineral Wool (Сб. научн. тр. «Технология теплоизоляционных и акустических материалов на основе минеральной ваты»). Vilnius, 1987, p. 84-90 (in Russian).

28. BLIŪDŽIUS, R. and SAMAJAUSKAS, R. Peculiarities of determining thermal conductivity coefficient of low density fibrous materials. Materials Science (Medžiagotyra), 2001, 7(4), p. 280-284.

29. GORSHKOV, V. S.; SAVELIEV, V. G. and ABAKUMOV, A. V. Binding, Ceramic and Glass-crystalline Materials. Structure and Properties (Вяжущие, керамика и стеклокерамические материалы. Структура и свойства). Moscow: Stroyizdat, 1995. 576 p. (in Russian). 


\section{MINERALIN S VATOS PLOKŠČIU STIPRIO GNIUŽDANT SAVYB S: STRUKTŪROS ANIZOTROPIŠKUMO IR METODINIŲ VEIKSNIŲ ITAKA}

\section{A. Buska, R. Mačiulaitis}

Santrauka

Pateikiami mineralin s vatos gaminių struktūros ir gniuždomojo ịtempio ar stiprio gniuždant tyrimai. Vizualiai ir mikroskopiškai tirti chaotiškos, kryptingos ir mišrios plaušo struktūros gaminiai. Mechaninių bandymų metu nustatyta, kad akmens vatos gaminiu gniuždomasis itempis (stipris gniuždant) priklauso nuo apkrovos veikimo krypties, bandiniu matmenų, apkrovimo greičio ir plaušo išsid stymo (orientacijos) bei metodinių ypatumų.

Reikšminiai žodžiai: mineralin vata, akmens vata, plaušai, struktūra, gniuždomasis ittempis esant $10 \%$ deformacijai, stipris gniuždant, deformacija.

Andrius BUSKA. PhD student. Dept of Building Materials. MSc (2005, materials science). Research interests: building materials, thermal insulation products, fibrous structure, mechanical behaviour.

Romualdas MAČIULAITIS. Doctor Habil, Professor. Head of Dept of Building Materials. Doctor (technical sciences, 1980). Doctor Habil (technical sciences, 1993). Professor (1999). Research interests: durability, frost resistance, fire prevention and other properties and processes of building materials and products. 